Division of Geological \& Geophysical Surveys

RAW-DATA FILE 2016-5

\title{
MAJOR-OXIDE AND TRACE-ELEMENT GEOCHEMICAL DATA FROM ROCKS COLLECTED IN 2010 IN THE TYONEK QUADRANGLE, ALASKA
}

by

Lawrence Freeman, Robert Gillis, Brent A. Elliott, and Alicja Wypych

$\$ 2.00$

March 2016

THIS REPORT HAS NOT BEEN REVIEWED FOR

TECHNICAL CONTENT OR FOR CONFORMITY TO THE

EDITORIAL STANDARDS OF DGGS

\author{
Released by \\ STATE OF ALASKA \\ DEPARTMENT OF NATURAL RESOURCES \\ Division of Geological \& Geophysical Surveys \\ 3354 College Road \\ Fairbanks, Alaska 99709-3707
}




\title{
MAJOR-OXIDE AND TRACE-ELEMENT GEOCHEMICAL DATA FROM ROCKS COLLECTED IN 2010 IN THE TYONEK QUADRANGLE, ALASKA
}

\author{
by \\ Lawrence R. Freeman ${ }^{1}$, Robert J. Gillis ${ }^{1}$, Brent A. Elliott ${ }^{2}$, and Alicja Wypych ${ }^{1}$
}

\section{INTRODUCTION}

Cook Inlet has been recognized as the second-largest petroleum province in Alaska, second only to the North Slope (LePain and others, 2013). The south-central Tyonek Quadrangle is an area of significant geologic interest because it is the only location in Cook Inlet where the entire producing stratigraphy of the basin is exposed on the surface (Magoon and others, 1976). Additionally, this area encompasses the structural boundary between the forearc basin and its sediment source rocks (Haeussler and Saltus, 2011; Hudson, 1986). To better understand the petroleum system and the geologic relationships between the exhumed arc intrusive rocks and adjacent Cenozoic stratigraphy of the Cook Inlet forearc basin, during the summer of 2010 the Alaska Division of Geological \& Geophysical Surveys conducted a federally-funded geologic field mapping project. As a part of this project DGGS collected 44 rock samples for geochemical analyses from Late Cretaceous and Paleogene intrusive and volcanic lithologies that compose part of the Alaska-Aleutian Range batholith and arc. Major-oxide, minor-oxide, and trace-element geochemical data presented here provide new information about the genesis and potential mineralization of igneous rocks in the western Neacola and southern Tordrillo mountains. Few such datasets for the area are publicly available, and those that exist are of a reconnaissance scope (Reed and Lanphere, 1969; 1973; Solie and others, 1993a, 1993b).

The analytical data tables associated with this report are available in digital format as comma-separated value (CSV) files. Additional details about the organization of information are noted in the accompanying metadata file. All files can be downloaded from the DGGS website (doi:10.14509/29651).

\section{DOCUMENTATION OF METHODS}

\section{SAMPLE COLLECTION}

Igneous rock samples showing little alteration or weathering were collected for whole-rock major-oxide, minoroxide, and trace-element analyses to aid in classification and study of their petrogenesis and tectonic setting. Most samples are 'grab' samples, which were collected for their overall representation of the outcrop. Location data were collected with handheld WAAS-enabled Garmin eTrex devices with location accuracy errors typically less than 10 meters; latitude and longitude were recorded and reported using the NAD27 datum.

\section{SAMPLE PREPARATION}

Rock samples were processed by ALS Minerals using their CRU-31, SPL-21, and PUL-31 methods. The samples were crushed to better than 70 percent passing $2 \mathrm{~mm}$, and a $250 \mathrm{~g}$ split was pulverized to better than 85 percent passing 75 microns. Prior to crushing, samples for whole-rock analysis were trimmed by DGGS staff to remove weathered surfaces.

\footnotetext{
${ }^{1}$ Alaska Division of Geological \& Geophysical Surveys, 3354 College Road, Fairbanks, AK 99709-3707; lawrence.freeman@alaska.gov

${ }^{2}$ Alaska Division of Geological \& Geophysical Surveys, 3354 College Road, Fairbanks, AK 99709-3707; now at University of Texas at Austin, Bureau of Economic Geology, Jackson School of Geosciences, P.O. Box X, Austin, TX 78713-8924
} 


\section{ANALYTiCAl Methods}

Samples were analyzed for a variety of suites of major and trace elements depending on the sample type. In addition to relying on ALS Minerals' accredited (ISO/IEC 17025-2005) internal quality-control program, DGGS monitored analysis quality with one standard reference material per batch of 20 analyses.

For whole-rock geochemistry samples, major and minor oxides were analyzed using lithium metaborate fusion digestion and XRF (ALS Minerals method ME-XRF06). Trace elements were determined using XRF on powder pellets (ALS Minerals method ME-XRF05).

For each sample, data tables contain either assay values or coded-value placeholders (null $=$ not analyzed; $-1=$ the element's assay result is less than the lower detection limit for the method; -2 = the element's assay result is greater than the upper detection limit for the method). Detection limits for each of the reported elemental values obtained by the various methods are documented in the metadata file.

\section{ACKNOWLEDGMENTS}

Primary funding for the Tyonek work was provided by the State of Alaska. Geologic mapping during the 2010 field season was supported by the U.S. Geological Survey's National Cooperative Geologic Mapping Program (STATEMAP award number: G10AC00321).

\section{REFERENCES}

Haeussler, P.J., and Saltus, R.W., 2011, Location and extent of Tertiary structures in Cook Inlet basin, Alaska, and mantle dynamics that focus deformation and subsidence, in Dumoulin, J.A., and Galloway, J.P., Studies by the U.S. Geological Survey in Alaska, 2008-2009: U.S. Geological Survey Professional Paper 1776D, 26 p.

Hudson, T.L., 1986, Plutonism and provenance-Implications for sandstone compositions, in Magoon, L.B., ed., Geologic studies of the lower Cook Inlet COST No. 1 well, Alaska Outer Continental Shelf: U.S. Geological Survey Bulletin 1596, p. 55-60.

LePain, D.L., Stanley, R.G., Helmold, K.P., and Shellenbaum, D.P., 2013, Geologic framework and petroleum systems of Cook Inlet basin, south-central Alaska, in Stone, D.M., and Hite, D.M., eds., Oil and gas fields of the Cook Inlet basin: American Association of Petroleum Geologists Memoir, v. 104, p. 37-116.

Magoon, L.B., Adkison, W.L., and Egbert, R.M., 1976, Map showing geology, wildcat wells, Tertiary plant fossil localities, K-Ar age dates, and petroleum operations, Cook Inlet area, Alaska: U.S. Geological Survey Miscellaneous Investigations Series Map I-1019, p. 3 sheets, scale 1:250,000.

Reed, B.L., and Lanphere, M.A., 1969, Age and chemistry of Mesozoic and Tertiary plutonic rocks in southcentral Alaska: Geological Society of America, Bulletin, v. 80, no. 1, p. 23-44.

Reed, B.L., and Lanphere, M.A., 1973, Alaska-Aleutian Range batholith-Geochronology, chemistry, and relation to circum-Pacific plutonism: Geological Society of America Bulletin, v. 84, p. 2,583-2,610.

Solie, D.N., Werdon, M.B., Nye, C.J., and Combellick, R.A., 1993a, Land selection unit 6 (Tyonek Quadrangle)—References, DGGS sample locations, geochemical and major oxide data: Alaska Division of Geological \& Geophysical Surveys Public Data File 93-6, 11 p. doi: $\underline{10.14509 / 1555}$

Solie, D.N., Werdon, M.B., Nye, C.J., and Combellick, R.A., 1993b, Land selection unit 7 (Tyonek and Kenai quadrangles)—References, DGGS sample location, geochemical and major oxide data: Alaska Division of Geological \& Geophysical Surveys Public Data File 93-7, 11 p. doi: $\underline{10.14509 / 1556}$ 